\title{
Removal of antibiotics from wastewater and its problematic effects on microbial communities by bioelectrochemical Technology: Current knowledge and future perspectives
}

\author{
Mahdi Hassan, Guangcan Zhu', Yong-ze LU, Ali Hamoud AL-Falahi, Yuan LU, Shan Huang, Ziren Wan \\ School of Energy and Environment, Key Laboratory of Environmental Medicine Engineering of the Ministry of Education, Southeast University, \\ Nanjing 210096, Jiangsu, China
}

\begin{abstract}
In this review, antibiotics are considered an emerging pollutant that has drawn worldwide attention in recent years. Therefore, the effective removal of antibiotic contaminants has become a hot issue in the field of environmental research. Most antibiotics applied to humans eventually enter municipal Wastewater Treatment Plants (WWTPs), because there are no appropriate commercially available pretreatment techniques. However, increasing anthropogenic activities, the high demand for animal-protein in developing countries as a nutritional alternative, and the extensive usage of antibiotics are mainly responsible for the persistence of antibiotic pollutants. One of the serious concerns regarding the presence of antibiotics in water and their potential role in exacerbating the emergence of antibiotics-resistance bacteria (ARB) and antibiotics-resistance genes (ARGs). In recent years, bioelectrochemical technologies are found promising for suppressing antibiotic contaminants through microbial metabolism and electrochemical redox reactions. Therefore, this review provides up-to-date insight research on bioelectrochemical systems (BESs), which improves the removal of the antibiotic in an efficient way. The focus of this review has been on the environmental sources of antibiotics, their health effects and possible degradation pathways, bacterial-antibiotics resistance mechanisms, and treatment of antibiotic-contained water using BES technology.
\end{abstract}

Keywords: Antibiotic resistance bacteria (ARB), Antibiotic resistance genes (ARGs), Bioelectrochemical System, Biodegradation, Microbial communities, Wastewater Treatment

\section{Introduction}

In the $20^{\text {th }}$ century, various antibiotics were developed to combat bacterial infections [1]. As a result, bacteria respond to antibiotic resistance by adapting to an increase in antibiotic levels in the environment. This phenomenon leads to a high proportion of antibiotic residues in livestock, municipal [2], and other industrial wastewater [3-5]. Nowadays, humans face a rapidly cumulative number of antibiotic-resistant strains. However, increased human activities, the high demand for animal protein sprees in developing countries [6,7], and the intensive use of antibiotics are the causes of the persistence of antibiotic pollutants in the environment [2, 8].

This contamination has raised more concerns because it could exacerbate the emergence of antibiotic resistant bacteria (ARB) and antibiotic resistant genes (ARGs) $[9,10]$. However, this issue raises serious concerns about public health [10, 11], as the ecological balance is threatened and continues to put pressure on the ARB and ARG. Also, ARB and ARG are moving globally on an unprecedented scale due to human activity, compared with the past billion years [2].

Moreover, the wastewater treatment plant only meets the existing standards; various emergent contaminants of pharmaceuticals and personal care products (PPCPs) [12] were released into the rivers and lakes without meeting satisfactory treatment $[13,14]$.

In recent years, different treatment methods have been carried out in terms of antibiotic residues, with significant removal efficiency. Advanced oxidation processes (AOPs) are of great concern due to their powerful removal efficiency $[15,16]$. Some antibiotics were prohibitive and may produce sub-active toxic by-products [17]. The effectiveness of antibiotic removal in the adsorption
This is an Open Access article distributed under the terms of the Creative Commons Attribution Non-Commercial License (http://creativecommons.org/licenses/by-nc/3.0/) which permits unrestricted non-commercial use, distribution, and reproduction in any medium, provided the original work is properly cited.
Received October 04, 2019 Accepted February 13, 2020

${ }^{\dagger}$ Corresponding author

Email: gc-zhu@seu.edu.cn

Tel: +86 2583795515 
process and membrane technology is satisfactory. But these techniques ultimately fail to degrade antibiotics and are significantly damaged by the presence of other organic pollutants. However, traditional biological methods were primarily noticed in terms of the high general performance of in-situ applications [18], but they are often time-consuming techniques [8, 19, 20].

Besides, bioelectrochemical technology combined with microbial fuel cells (MMCs) and microbial electrolytic cells (MECs), with bacterial metabolism and the electrochemical-redox reactions, were considered promising alternatives to degradation. Similarly, these systems have been used to improve the removal rate of antibiotics sulfamethoxazole (SMX) through redox reactions [21, 22]. Harnish et al. [23]. revealed the method of degradation of SMX $6.0 \mathrm{mgL}^{-1}$ in a microbial electrolytic cell within seven days. Another study by Zhang et al. [24] observed that the removal rate of $200 \mu \mathrm{gL}^{-1}$ of sulfamethoxazole (SMX) in a three-dimensional biofilm electrode reactor (3D-BER). The system reached 85.5 - 90\% removal with hydraulic retention time (HRT) of $40 \mathrm{~h}$. While the multipurpose treatment of solid-phase mixtures (granular activated carbon), Song et al. [25] demonstrated that the removal performance of antibiotics in 3-Dimensional biofilm electrode reactors (3DBER), in solid phase environment and integration possibilities with other technologies, as shown in Table 1.

Furthermore, the bioelectrochemical technology has the following advantages; (a) eco-friendly: 3-amino-5-methylisoxazole, highly bio-toxic sulfamethoxazole (SMX) intermediate that was further degraded by microbial fuel cells. In addition, the use of biocathodes also circumvents the production of highly toxic by-products of nitrofurazone (NFZ) and Chloramphenicol (CAP); (b) various antibiotic removal by constructed wetlands; (c) cost-effective: biocathodes and some external power inputs in BESs does not require additional reducing agents and therefore has high efficiency of antibiotic removals illustrated in Fig. 1. Bioelectrochemical technology shows both promising results $[15,26]$ on the excellent removal efficiency of a variety of other toxic-compounds in laboratories and full scales systems [27]. Municipal wastewater containing antibiotics had a critical problem due to improper wastewater treatment and a high level of toxicity in the environment [28, 29].

The aim of this review is to provide comprehensive details of the effects of bioelectrochemical technology on antibiotics pollutants removal with a broader perspective. Therefore, this systemic review primarily focuses on the mechanisms and degradation pathways of the various types of antibiotics and antibiotic-resistant genes. The special effects on the antibiotic-resistant bacteria and antibiotic-resistant genes and possible biodegradation process were also discussed. The present challenges and future scope of research on the latest technologies for the effective removal of antibiotics have also been discussed.

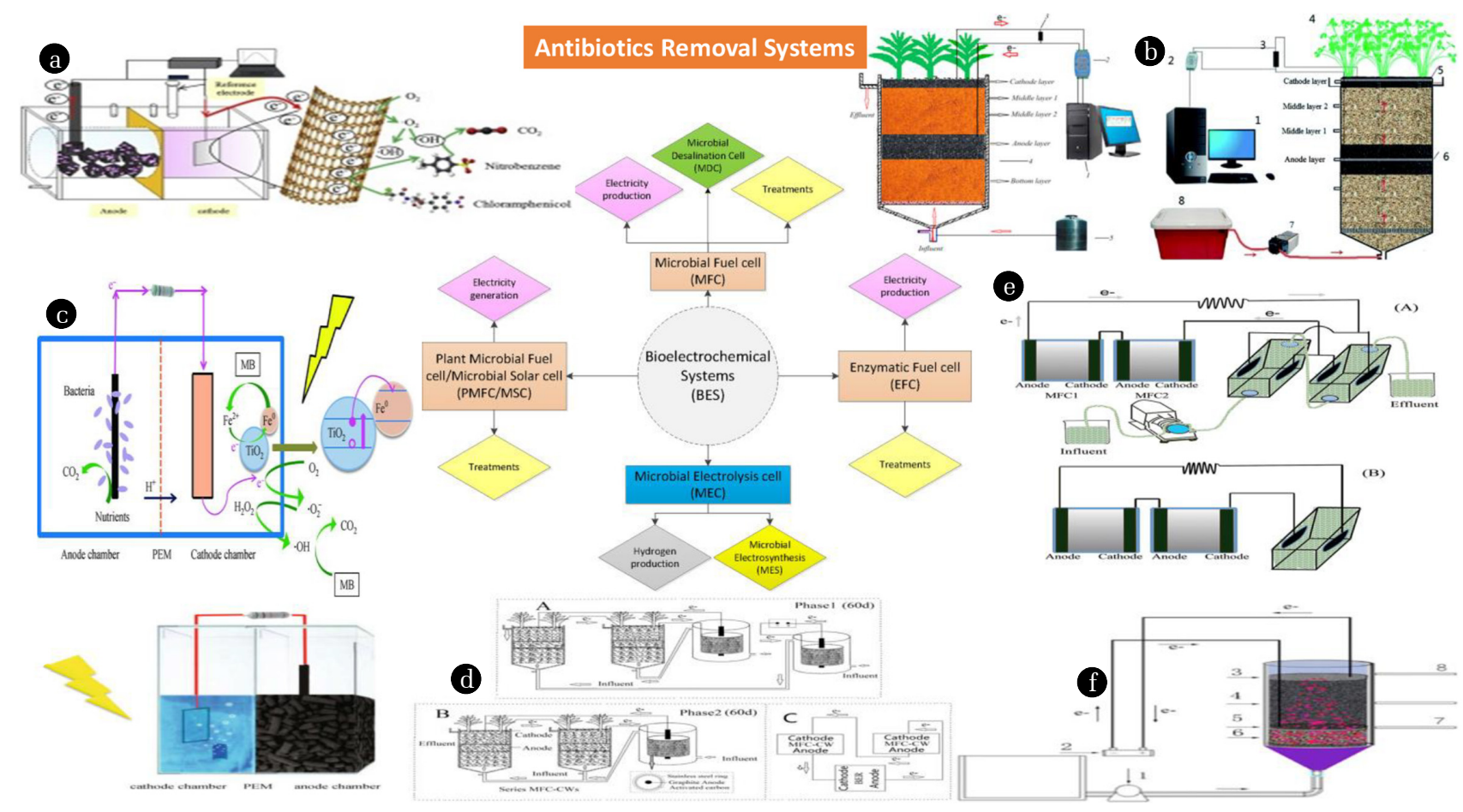

Fig. 1. Representation Illustrations of the different treatment processes of antibiotics removal and the main grouping of bioelectrochemical systems. (a) Advanced oxidation process coupled with BES. Reproduced with approval from references [30]. (b) Constructed wetlands coupled with a microbial fuel cell. Reproduced with approval from references [31]. (c) BES-AOP-coupled with advanced oxidation process with the cathode $\left(\mathrm{FeO} / \mathrm{TiO}_{2}\right)$, and (B): design of the MFC-PEC System. Reproduced with approval from references [32]. (d) The coupled Constructed wetland with a biofilm electrode reactor system (CW-BES-MFCs). Reproduced with approval from references [33]. (e) A Configuration of microbial fuel cell (MFC-sorption) System. Reproduced with approval from references [34]. (f) 3D-BER: Three-dimensional biofilm electrode reactors. Reproduced with the approval from references [24]. 


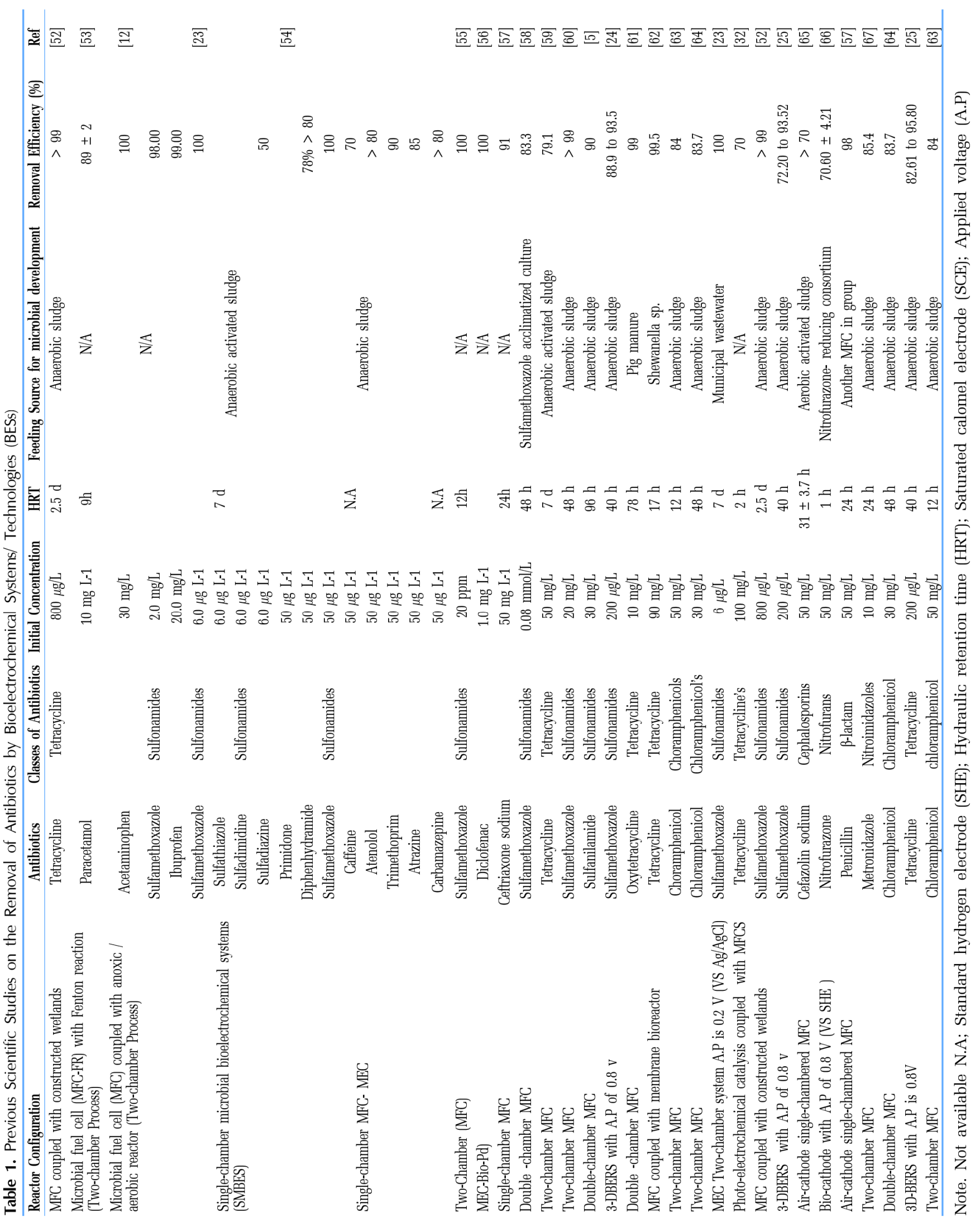




\section{Sources of Antibiotics-polluted Water}

Several antibiotics and their metabolites were secreted continuously discharged into the natural environment. Moreover, from the veterinary, pharmaceutical plants, dairy plants, habitat, animal waste, animal husbandry, hospital waste, municipal waste, and poultry waste releases directly into the environment [35]. Antibiotics, known as monensin, promote animal growth and feed efficiency in dairy farms to achieve natural resources. Therefore, antibiotic residues indirectly contaminate soil and water resources [36, 37]. While the consumption of antibiotics in plants is deficient compared to animals. Antibiotics are commonly found in waterways in the countryside and are widely used in agricultural land. In addition to household and industrial wastewater, the pharmaceutical industry has a significant contribution to the increased total antibiotic concentration in wastewater treatment plants [37]. Some antibiotics have a low molecular weight $(<1,000 \mathrm{D})$ and therefore, dissolve rapidly in water, leading to persistence and reflection of antibiotics (i.e., sulfonamides and tetracycline's) and their isomers [38]. The overall characteristics and removal techniques of some imperative antibiotics by BES. On the worldwide scale, sewage treatment plants (STPs) could not remove pollutants properly, such as nitrates, organic, and antibiotics, in the effective ways, so they continue to flow into sediments and water bodies in our surroundings. Disposal of improper treatment of antibiotics might be considered an essential point of pollution, and these drugs were discharged directly into the sewer system or deposited in landfills, production wastewater, or unintentional wastewater during production or distribution [38].

\subsection{Removal of Antibiotics Using Different Systems}

It can efficiently degrade antibiotics [39], but in the process of BES degradation of antibiotics [40], it is necessary to understand the fate of ARB and ARGs [39, 41]. The main operational factors of BES, for instance, cathodic-potentials, have a potential influence on the occurrence and abundances of ARB and ARGs [42, 43]. For example, the applied electrical Stimulation can affect the physical properties of bacteria as a cross-membrane potential [44], and membrane permeability [45], Lead to changes in ARB and ARG abundance in bioelectrochemical systems [46]. Also, compared with WWTPs, less sludge would be produced in anaerobic bioelectrochemical systems (BES) [47, 48]. This avoids the proliferation of antibiotic genes during sludge disposal[30], however, most researchers are focusing on the spread of antibiotic-resistant bacteria and ARG in wastewater treatment plants [48], and very truncated information was available about the occurrence and abundance of ABR [49] and antibiotic resistance genes in the BES. Electrodes for innovation, a variety of application development and design of the membrane and catalyst of alternative materials to make BES become a promising technology [50, 51]. The usage of BESs for the elimination of toxic pollutants is not yet widespread. Whereas the previous studies are presented in Table 1.

\section{Control Techniques of Antibiotics}

Bioelectrochemical technologies have been used to degrade anti- biotics by different substrates and mechanisms [68]. The purpose of removing pollutants from municipal wastewater treatment plants is to reduce the concentration of organic pollutants, antibiotics, and its different by-products [21, 68]. BES technologies effectively remove antibiotics with minimum time; however, aerobic and anaerobic conditions in the bioelectrochemical systems [8, 69], so catalysts may be used for the antibiotics elimination [42, 70]. Hence, removal methods can be divided into the following categories:

\subsection{Microbial Electrolysis Cell with Bio-cathode}

For the latest system of Bio-cathode for hydrogen $\left(\mathrm{H}_{2}\right)$ production in the microbial electrolytic cell (MEC) has a favorable substitute for precious metal catalysts. In this system, biological cathode usually made as, i.e., MEC was supplied through external energy since the reduction potential of antibiotics was always higher in the bioanode (Fig. 2(A)) [71, 72]. For minimizing the total power consumption, the anode of the system operates continuously as a combined microorganism [10]. Antibiotic control techniques were performed primarily associated with direct electrochemical reduction and biodegradation [40]. Though the antibiotics gained electrons from the cathode and were reduced directly by the electrochemical reduction [40, 41]. Since the biocatalysts rapidity up and then the decline of antibiotics by reducing the power consumption [40], microorganisms thrive on the cathode electrode [66]. It is another feature of the microbial communities in which carbon sources and substrates were used in bio-cathodic chambers, and bio-cathodes were further categorized with a mixture of different materials matrix. The relevant regulations under consideration as biocatalysts can be developed and activated in the following main three categories: (a) Full-biological two-chambered biocathodes microbial electrolytic cell (MEC); (b) MEC of Full-biological single-chambered biocatalysts MEC; (c) half-biological two-chambered biocathodes MEC. Further, to identify a variety of mixed cultures that produce hydrogen, and it has detected in pre-dominant microbial species $[66,73]$. If the reduction potential of antibiotics is higher than the biological anode of the systems can also be worked as bio-cathode without using an external power source [41, 71, 73].

\subsection{Microbial Fuel Cells (MFCs) with ORR Cathode Catalysts}

MFC was mainly used for wastewater treatment, the characteristic of oxygen reduction reaction (ORR) was expected to have high catalytic activity, so the capital costs and maintenance costs should be comparable to conventional processing technologies. In this category, MFC consists mainly of biological anodes and abiotic cathodes. Two chamber-MFC or oxygen in abiotic cathodes (Air cathode with single-chamber MFC) was commonly used as an electron acceptor in abiotic cathodes illustrated in Fig. 2(B) [74].

In the biological anode, antibiotics were used as electron donors and played an active role in carbon sources. The exoelectrogenic microorganisms and degradable antibiotics bacteria observe to the anode, to form a biofilm in the extracellular polymer material, it plays a role to reduce the super-potential of biologically incontrollable antibiotic and their bio-metabolites. The combination of anaerobic biodegradation and electrical stimulation is an important mechanism for supporting antibiotic mineralisation in microbial fuel cells. By continuous electrical stimulation (ES) directly stim- 
ulates electron and microbial metabolism in the micro-environment by directly or indirectly transferring electrons to bacterial cells [75]. However, rapid stimulation of microorganisms to metabolize antibiotics by secreting enzymes, such as 3-amino-5-methylisoxazole (3A5MI), and their by-products [55].

\subsection{Bioelectrochemical System with Modified Materials}

It is considered to be one of the most effective techniques to remove uncontrollable organic contaminants. It depends on three different cathodes, i.e., nickel foam (NF), Copper foam (CuF), carbon rods (CR), for antibiotics chloramphenicol (CAP) removal in BES System, while $\mathrm{NF}$ and $\mathrm{CuF}$ were not used as cathodes for CAP degradation previously. While the modified materials, targeted antibiotics, are often attacked to produce free radical species decomposition for the BES cathode. This equation shows the following main reactions; (i) Air is used to produce hydrogen peroxide $\left(\mathrm{H}_{2} \mathrm{O}_{2}\right)$ from a pump or Cathode material that absorbs electrons (e-) to reduce dissolved oxygen, i.e., $\mathrm{O}_{2}+2 \mathrm{e}^{-}+2 \mathrm{H}^{+} \rightarrow \mathrm{H}_{2} \mathrm{O}_{2}$; (ii) Electrons generated by the transfer of the bioanode to the surface of the cathode material transfer through an external circuit; and (iii) hydrogen peroxide $\left(\mathrm{H}_{2} \mathrm{O}_{2}\right)$ below UV light or cathodic material can be produce radical species/microorganism, approximating, hydroxyl radicals $(\mathrm{OH})$ which oxidise and rescind antibiotics paternities, i.e. $\mathrm{H}_{2} \mathrm{O}_{2}+h V \rightarrow$ $2 \mathrm{OH} \cdot$ and antibiotics ${ }^{+} \mathrm{OH} \cdot \rightarrow$ degradation products.

Kin Wu et al. [30] revealed the rapid degradation of Chloramphenicol (CAP) in copper foam (CuF) cathode, in-situ the production of hydroxyl radicals, direct electrochemical reduction affects the cathode (Fig. 2(C)). Additionally, the modified cathode of photochemical and electrochemical catalytic materials $\left(\mathrm{FeO} / \mathrm{TiO}_{2}\right)$, efficiently produced hydroxyl radicals $(\bullet \mathrm{OH})$, and rapid degradation of tetracycline (TC) and ARG by invisible electrons generated by bio-anodes has shown in (Fig. 2(D)) [32, 76].

\subsection{Removal of Antibiotics by Single-double Microbial Fuel Cell}

The detection of trace amounts of organic pollutants and different types of antibiotics, in Single chamber microbial fuel cell (SC-MFC) and double chamber microbial fuel cell (DC-MFC) with sodium acetate $\left(\mathrm{C}_{2} \mathrm{H}_{3} \mathrm{NaO}_{2}\right)$ as co-substrate were investigated. The contribution of MFC to the energy production of trace organic compounds is negligible. Similarly, microbial fuel cell operation has a smaller amount of removal quantity of contaminants, but longer Hydraulic retention time (HRT) enhanced biodegradability [77]. Approximately, various parameters that primarily affect individual contamination removal and efficiency were hydrophobic compounds that tend to gain to the electrodes. Due to the observation of positively charged toxins into interaction with negatively charged biofilms, dissolved oxygen (DO), and $\mathrm{pH}$. For the best removal efficiency obtained by replacing the anode with a single chamber MFC and a cathode of double-chamber MFC. The biofilms can also successfully remove antibiotics (sulfonamides and $\mathrm{N}_{4}$-acetyl metabolites) from wastewater [78]. The wastewater was containing

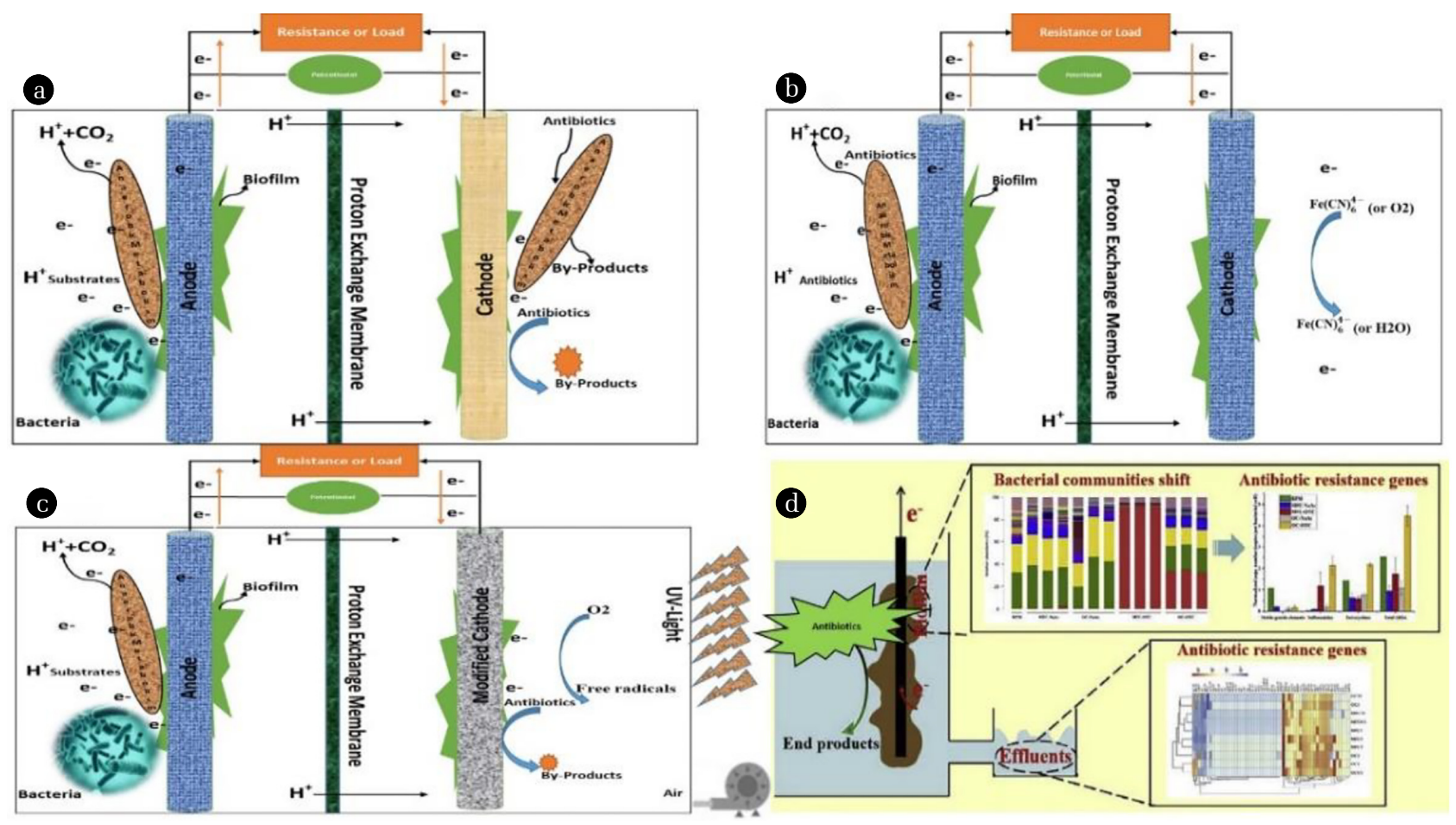

Fig. 2. Schematic of Antibiotics removal methodologies based on BES Technology (a) Schematic diagrams of MFC and MEC by standard potentials (vs NHE) of oxidation and reduction reactions in anodic and cathodic chambers, resulting in a spontaneous response in MFC and a nonspontaneous reaction in MEC. Reproduced with approval from references [71]. (b) Systemic illustrations of to reduce antibiotics by a biological anode coupled with the biological-cathode. Reproduced with approval from references [75]. (c-d) An anode connected to the cathode compartment of the biological system by removal of the antibiotic Chloramphenicol (CAP).Reproduced with approval from references [30, 32]. 
sulfamethoxazole, sulfamthiazole, sulfadiazine, sulfamethazine sulfonamide, and their N-4-acetyl analogues in a mixture treated with acetic acid added to the biofilm anode [23, 79]. The electrochemical performance of the biofilm was not exposed to sulfonamide influence: the trace contaminants poisoning Colomb efficiency remains unchanged, and a marginally increase in the current density [54]. Whereas the concentrations of sulfathiazole $\left(\mathrm{C}_{9} \mathrm{H}_{9} \mathrm{~N}_{3} \mathrm{O}_{2} \mathrm{~S}_{2}\right)$, and sulfadimidine $\left(\mathrm{C}_{12} \mathrm{H}_{14} \mathrm{~N}_{4} \mathrm{O}_{2} \mathrm{~S}\right)$ were almost constant, sulfamethoxazole was eliminated, and only sulfadiazine $\left(\mathrm{C}_{10} \mathrm{H}_{10} \mathrm{~N}_{4} \mathrm{O}_{2} \mathrm{~S}\right)$ was removed [23, 49, 79].

\subsection{Power Density at Different Substrates}

MFCs single-chamber with the air cathode shows the use of glucose-penicillin $\left(\mathrm{C}_{9} \mathrm{H}_{11} \mathrm{~N}_{2} \mathrm{O}_{4} \mathrm{~S}\right)$ as a successful fuel [80]. While the result indicates that penicillin can produce electricity at the same time as biodegradable, and the glucose-penicillin mixture plays an important role in the production of energy [53]. Glucose $\left(\mathrm{C}_{6} \mathrm{H}_{12} \mathrm{O}_{6}\right)$ $1.02 \mathrm{~g} / \mathrm{L}$ and $50 \mathrm{mg} / \mathrm{L}$ penicillin mixture, the power density was six times higher than $101.20 \mathrm{w} / \mathrm{m}^{3} \mathrm{~L}$ and $1.0 \mathrm{~g}$ acquired glucose $\left(\mathrm{C}_{6} \mathrm{H}_{12} \mathrm{O}_{6}\right) 14.70 \mathrm{~W} / \mathrm{m}^{3}$, and $50 \mathrm{mgL}^{-1}$ penicillin of $2.10 \mathrm{~W} / \mathrm{m}^{3}$ as a total of power density obtained an alternative fuel. Though, estimated the penicillin $\left(\mathrm{C}_{9} \mathrm{H}_{11} \mathrm{~N}_{2} \mathrm{O}_{4} \mathrm{~S}\right)$ can increase the permeability of electroactive bacteria cell membranes (EABCM), endorse direct electron transfer from microorganisms to the anode, and reduce the internal resistances of MFC [29]. By the mixed medium, the deterioration of penicillin has approximately $98 \%$ efficiency at the $24 \mathrm{~h}$ batch cycle. However, the presence of this mixture similarly increases the ability of the degradation of the organic substrate [57]. The biodegradable organic matter contained antibiotic wastewater might be the appropriate resources for the generation of electricity by the MFC system [57, 81].

\subsection{Toxicity-reduction Processes}

The applicability of MFCs to the disposal of antibiotics in wastewater [55]. Wang et al. [82] demonstrated his scientific research shows that MFCs apparatuses can successfully degrade the Sulfamethoxazole and its degradation products; 3-amino-5-methylisoxazole (3A5MI). Moreover, the adenosine triphosphate (ATP) level of MFC microorganisms is almost triple higher than open circuit control, although it may be related to the fast degradation of Sulfamethoxazole (SMX) in a microbial fuel cell (MFCs) [30, 53]. The mass spectrometry was detected the degradation products of SMX, and chemical standards confirmed the inference of three by-products. In accumulation, 3-amino-5-methylisoxazole (3A5MI) is a toxic chemical formed during the process of SMX degradation and can be more mineralized. In the process of degradation, the SMX, nitrogen $\left(\mathrm{N}_{2}\right)$ atoms are observed to be gradually eliminated, which should be related to the removal of SMX antibiotics and 3-amino-5-methylisoxazole (3A5MI) [82]. Antimicrobial activity tests have displayed that the bio-toxicity effect of SMX on "Escherichia coli and Shewanella oneidensis" was significantly reduced the treatment of microbial fuel cell (MFC) afterwards [55, 83, 84].

\subsection{Biotransformation Systems}

Microbial fuel cells (MFC) and microbial electrolysis cells (MEC) are two microbial electrochemical systems that convert chemical energy into wastewater by microorganisms [54].Worthwhile energy sources such as bio-electricity from a microbial fuel cell and hydrogen $\left(\mathrm{H}_{2}\right)$ gas from the microbial electrochemical cell. For the attenuation of organic trace compounds in synthetic wastewater, acetic acid used as a carbon source in a single-chamber reactor with standard hydrogen electrode since from $-0.40 \mathrm{~V}$ vs. SHE anode potential $[57,78,82]$. Adding fungicides of sodium azide $\left(\mathrm{NaN}_{3}\right)$, to the repeating system to distinguish the observed attenuation and the effect of biotransformation in the adsorption composition [78]. In MFCs and MECs, research carried out of eight compounds have similar attenuation effects, except Trimethoprim and caffeine, which has a slightly higher reduction [54]. The adsorption of the biofilm on the electrode is very large, but there is no consistent tendency to the physicochemical properties and adsorption degree of the adsorption compounds. The maximum current density/demand of the MFC/MEC remains unchanged before and after the number of trace contaminants of Carbamazepine $80 \%$ removal $[54,85]$. The elimination efficiency was good, and the main pathway of eradication was determined in the anodic adsorption of biofilm [146]. As attention to the removal of trace organics, collective bioelectrochemical systems did not exhibit a particular advantage (or disadvantage) in conventional processes. These systems can be considered similar, thus maintaining the observed toxicity of the pollutants obtained in bioelectrochemical systems (BES). The preference of using the bioelectrochemical process for energy production in wastewater treatment does not affect the degradation of trace organic matter, but its applicability necessity considered in a more extended assessment $[54,86]$. Several benefits of the specific capabilities of the bioelectrochemical system have also been improved, including technical integration or capacity expansion [54, 86, 87].

\section{Main Systems for removal of antibiotics}

\subsection{Role of Bio-palladium (Bio-Pd) Catalyst Added with MECs}

A novel bio-palladium (Bio-Pd) nanoparticles used as catalysts in the microbial electrolysis cell to remove iodinated contrast mediocre amidotrizoate (diatrizoate) from hospital wastewater [56]. The presence of Bio-Pd indicates that this is not only directly electrochemically reducing contaminants on the cathode, but it was also possible to enhance the catalytic reduction of hydrogen gas $\left(\mathrm{H}_{2}\right)$ production [88]. The system operated continuously synthesized and later discharged from the hospital wastewater in batch mode. The synthetic feed used to observe complete elimination with applied voltage from $-0.60 \mathrm{~V}$ to $-0.8 \mathrm{~V}$. In the actual wastewater, the voltage applied at $-0.8 \mathrm{~V}$ is $84.2 \%$, the removal rate after $24 \mathrm{~h}$ is $84.90 \pm 7.6 \%$. In continuous mode, the voltage of -0.80 $\mathrm{V}$ (HRT $=4$ to $8 \mathrm{~h}$ ), while the synthetic feed is low (95\% at HRT $=4 \mathrm{~h}$ and $96 \%$ at HRT $=8 \mathrm{~h}$ ), with hospital wastewater. De Gusseme et al. [88], established the method of catalytic dechlorinating of diclofenac by biogenic palladium (bio-Pd) in MECs. At the application voltage of $-0.8 \mathrm{~V}$, the maximum batch effect was obtained and diclofenac removed after $3 \mathrm{~h}$. In continuous mode, the minimum $\mathrm{HRT}=2 \mathrm{~h}$ was required to completely remove diclofenac in the 
case of an applied voltages of $-0.80 \mathrm{~V}$. When applied voltages on continuous modes of hospital wastewater effluent, have the removal efficiency of $57 \pm 90 \%$ at $-0.8 \mathrm{~V}$ and HRT $=8 \mathrm{~h}$ were observed, mainly because of the low concentration of pollutants in the wastewater and the presence of disruptive substances [56, 88].

\subsection{Dual Chamber MFC Coupled with Biological $\left(A^{2} / 0\right)$ System}

A novel system with a dual-MFC chamber $\left(\mathrm{MFC}^{2} \mathrm{~A}^{2} / \mathrm{O}\right)$ process with a "proton exchange membrane" (PEM) and solid plain graphite plates. The electrodes, in combination with anoxic-aerobic $\left(\mathrm{A}^{2} / \mathrm{O}\right)$ for the biological degradation of concentrations in wastewater, sulfonamide (sulfonamide), ibuprofen, and very high paracetamol, which is reduced simultaneously [18, 89]. Moreover, three pharmaceutically active compounds (PhACs) with high removal efficiencies ranging from $98.21 \%$ to $99.89 \%$ were obtained. The main purpose of using a single reactor within the anaerobic process for the development of facultative bacterial inhabitants in anodes and mixed liquor was better than aerobic reactions [90]. However, the maximum power density was $5.30 \mathrm{w} / \mathrm{m}^{2}$, and the maximum Coulomb efficiency or current efficiency of the anode was approximately $25.2 \%$. The differences in the abundance of bacterial communities in different parts of the MFC-A ${ }^{2} / O$ system were observed [12, 91].

\subsection{Paracetamol (PAM) Removal by Fenton System}

Dual-chamber MFCs were developed to achieve biodegradation of paracetamol using microbial fuel cells by the Fenton process and did not use external feeding sources [92]. In the anode chamber, the degradable oxidation pollutants with low current intensity in domestic wastewater effluent and released electrons from the system. Additionally, in the cathode, the electron flux $(\Phi)$ of the anode facilitates the increase of free radicals to form hydroxyls radical $(\mathrm{OH})$ in the regeneration of the external iron sources [93]. The $\mathrm{pH}$ levels at different due to the adjustable concentration dose that allows a typical oxidation reaction during the Oxydrile radicals, which produces a base after the initial electrochemical reduction. The optimal condition of the process is $5.0 \mathrm{mg} \mathrm{F} / \mathrm{L}, \mathrm{pH}=2.0$. Under the best conditions, the performance of the system with the bio-electric power capacity of the MFC reactor is virtuous [53, 94]. The maximum degradation efficiency of PAM was $70.0 \%$ within $9 \mathrm{~h}$ and $25.0 \%$ to obtain complete mineralization, and most of the metabolites p-nitrophenol $\left(\mathrm{C}_{6} \mathrm{H}_{5} \mathrm{NO}_{3}\right)$ is converted, and a very fewer vulnerable dicarboxylic/carboxylic (carboxyl functional groups) acid [94, 95]. It shows that the results suggest that the MFC-Fenton process can be used as an energy-efficient method for the treatment of PAM-containing wastewater and the degradation of non-biocompatible drugs in the aquatic environment [53, 93].

\section{Performance of Antibiotics in Bioelectrochemical}

\section{Technology}

\subsection{Removals Performance of Antibiotics}

Another significant factor is the biological factor, which acts as biocatalysts and then decomposes the substrates that affect the electron transfer rate and the bioelectricity generation [21, 71]. The core part of MFC-biocatalysts is a variety of biochemical pathways, which can be used to obtain various electronic transmission mechanisms according to the parameters designed for MFC [21, $96,97]$. In the current review, the discussion of the key factors that regulate the performance of MFC, according to the bioelectronic mechanism. From the literature, some scientific studies on the removal of pollutants from BES indicate that MFC performance is affected by many factors [96]. Hence, apply the system in the future; it has necessary to discuss the influence of the parameters in detailed. However, other various parameters like immunization, additives, flow rates [71, 96], $\mathrm{pH}$ values, and buffer solutions have been determined [98, 99]. The electrochemical-properties of antibiotics and the many physico-chemical properties of the pollutants such as the initial concentrations, toxicity of salts [99], and the various applications of applied potential, electrodes, temperature, environmental factors, carbon sources, and salinity were also discussed. The effect on electrochemical performances, including energy production capacity, antibiotic removal efficiency, and conversion of degradation by-products [71, 98].

\subsection{Substantial Selection for Antibiotics}

The substantial selection is the basis for the overall performance of bioelectrochemical technology, as microorganisms flourish and form biofilm for electron transfer in electrodes as biocatalysts [100-102]. Many researchers use carbon felt as an electrode material [103]. However, there has been limited research into the properties of various electrode materials for wastewater treatment, including antibiotics. Only one main studied found by Wang et al [30], which the degradation effect of the cathode electrode in the antibiotic chloramphenicol (CAP) treatment of the three metal foams in BET. Copper foam $(\mathrm{CuF})$, carbon rods, and nickel foams $(\mathrm{NiF})$ are the best off-hat properties of cathode electrodes. However, the $32 \mathrm{mg} / \mathrm{L}$ chloramphenicol (CAP) were removed using copper foam electrodes [102] within $12 \mathrm{~h}$, which was further based on the carbon rods after $24 \mathrm{~h}$, and nickel foam more than $120 \mathrm{~h}$ [10, 77]. Antibiotics chloramphenicol is the main product, using carbon rods and foam nickel electrodes with copper foam electrodes, and completely mineralized with $\mathrm{CO}_{2}$ and $\mathrm{H}_{2} \mathrm{O}$, each with nitrobenzene $\left(\mathrm{C}_{6} \mathrm{H}_{5} \mathrm{NO}_{2}\right)$, and 4-nitrobenzene alcohol. They revealed a reduction in the current of the material based on the Cyclic voltammetry (CV) results [30]. By comparing the carbon rods with the foam nickel electrodes, the highest reduction current is obtained by using the copper foam electrodes. The aim of sustainable development of a bioelectrochemical Technology can be able to develop electrode materials such as biochar and reforming materials to improve the redox reaction rate for low-cost environmental protection. The interaction between the electrodes and the microorganisms and the interaction between the electrodes and the antibiotics must be paid more attention. For example, the modified electrode leads to an increase in gene expression associated with electron transfer, whether to further improve the electron transfer rate involved in antibiotic degradation of the redox reaction [49, 77].

\subsection{Importance of Carbon Source for Removal of Antibiotics}

The vital contribution of carbon sources performing a significant 
role in the balance between microbial communities and metabolic activities $[104,105]$. All research of that area has focused on other carbon sources (antibiotics was the only source of carbon), and BES did not have the features of inorganic and organic carbon [104]. The feasibility and effectiveness of anodic-oxidation of sulfamethoxazole (SMX) [84] in MFC in an oligotrophic environment [55]. Deprived of additional carbon sources, SMX was the only source of nitrogen [60] and carbon that is highly extinguished to $\mathrm{CH}_{4}$ as the final degradation product [55, 61]. This specifies that the metabolic capacity of the microbial community using antibiotics as a separate carbon source has improved significantly. Kong et al. [66] to investigate the effect of inorganic carbon source $\mathrm{NaHCO}_{3}$ on the bio-catalytic metabolism of NFZ removal. However, it showed that the rate constants and NFZ reduction removal efficiencies in bioanode fed with $\mathrm{NaHCO}_{3}$ were slightly lower than those with added glucose but significantly better than non-biological cathodes. This means that the biocathodes fed with $\mathrm{NaHCO}_{3}$ still has significant bio-catalytic capacity reported [60, 106]. Furthermore, many scientific studies have been based on enthusiastically biodegradable carbon sources such as glucose and acetate as a common substrate to improve antibiotic treatment [55, 60]. The yield of MFC using glucose and penicillin as a co-substrate is nearly 48 times higher than that of MFC containing only penicillin as a substrate [57]. The observation suggests that the addition of common substrates provides enough carbon sources and more electron donors to improve the metabolism of the microbial communities.

\subsection{Removal of Antibiotics by Applied Voltages}

Changes in applied potentials voltages lead to electrochemically active biofilm with different degrees of electrical stimulation, and the number of electron donors [107], affecting on the mineralization of antibiotics is different [108]. Based on previous studies, additional negative application potentials significantly improved the elimination of antibiotics and significantly reduced the HRT of biocathodes [107]. Nitrofurazone reduction constant rate of 0.6770 \pm 0.690 per hour and reduction efficiency of $42.250 \pm 1.351 \%$ at $1.0 \mathrm{~h}$, when the voltage was applying to $-0.2 \mathrm{~V}$, then the coefficients increased from $1.202 \pm 0.124 / \mathrm{h}$ and $70.60 \pm 4.21 \%$. Similarly, on a cathode potential of $-0.8 \mathrm{~V}$ [66]. Additional, as the cathode voltage is high, the conversion of the degradation intermediate is achieved faster. In Sodium bicarbonate (NaHCO3) fed bio-cathodes, 3-(5-Nitro-2-furyl) acrolein (NFF), and [(5-amino-2-furyl)-methylene]-hydrazinecarboxamide, and the products remarkably accumulated in $72 \mathrm{~h}$ at -0.2 Volts, equally support to degraded and disappeared within $48 \mathrm{~h}$ at $-0.80 \mathrm{~V}$ [30, 66]. Increasing the applied voltage have escalations the elimination efficiency of the CAP [107, 109]. Guo et al. [110, 111] demonstrated that the CAP removal efficiency increased with the increase in cathode potential from $-0.50 \mathrm{~V}$ to $-1.25 \mathrm{v}$; vs. SHE. The increase in cathode potential is closely related to the high removal rate of CAP antibiotics. However, if the applied potential of external is meagre, then the total energy consumption will be raised. Therefore, in the future, it is necessary to consider the possibility of optimizing the applied potentials to reduce energy consumption while maintaining the efficiency of the degradation of antibiotics.

\subsection{Removal Efficiency of Antibiotics}

The pollution capacity of the system is increased, and it is easy to see that the initial concentration of antibiotics increased progressively. So, it was tough to need more time and power to remove them $[7,112]$. It has been pointed out that the degradation efficacy of the CAP in the biocathodes decreased with the increase of concentration [110]. Comparable as the SMX concentration increases from $20 \mathrm{mg} / \mathrm{L}$ to $200 \mathrm{mg} / \mathrm{L}$, the half-life of SMX removal in MFC extension from $24 \mathrm{~h}$ to $72 \mathrm{~h}$. The results show that the degradation efficiency of antibiotics depends to some extent on the initial concentration [60].

However, some studies have provided conflicting experimental results, that the higher concentration of antibiotic, the improved BES performance was reported. In single-chamber MFC, the removal rate of $50 \mathrm{mg} / \mathrm{L}$ ceftriaxone-sodium was much higher than $30 \mathrm{mg} / \mathrm{L}$ [81]. According to the electrochemical-impedance spectrum and anode terminal discharge performance, ceftriaxone-sodium incidentally affects the redox enzyme of microorganisms, resulting in an overall decrease in MFC resistance [57]. Though similar results were obtained in other MFC related studies [19, 113-115]. Therefore, as the concentration of penicillin increases, the power generated by MFC has also increased [116]. As for concerned that some researchers have reported that the performance of the BESs remains the same as the initial concentration of antibiotics increases. The anode biofilm of the cefazolin sodium was satisfactorily acceptable [65]. The anode biofilm has been exposed continuously to increased levels of cefazolin sodium from $50 \mathrm{mg} / \mathrm{L}$ to $450 \mathrm{mg} / \mathrm{L}$ and does not show a voltage drop of more than 1,200 h during MFC operation. The thickness of the extracellular polymer material and biofilm may be a toxin used to quench these antimicrobial compounds $[65,117]$. One more example was that the voltage output of MFC had relatively high reported to be stable when the $500 \mathrm{mg} / \mathrm{L}$ to $1.0 \mathrm{mg} / \mathrm{L}$. Finally, these scientific studies have shown considerable impact load capacity, providing scientific-reference for the treatment of antibiotic-containing pharmaceutical wastewater by bioelectrochemical systems [118].

\section{Relationship between Temperature and Bacterial Growth}

Very few scientific studies have presented that temperature can significantly affect the growth of bacteria [119], metabolic activities, and advance biochemical reactions associated with antibiotics treatment [120, 121]. Zhang et al. [63] envisioned single factor experimentation to explore the various effect of the temperatures $\left(20^{\circ} \mathrm{C}, 30^{\circ} \mathrm{C}\right.$, and $\left.40^{\circ} \mathrm{C}\right)$. They achieved a higher removal efficiency of CAP was $75.13 \%$ at $40^{\circ} \mathrm{C}$, compared with $68.11 \%$ at $20^{\circ} \mathrm{C}$. Guo et al. [111] examined the removal efficiency of CAP antibiotics in BESs at $10^{\circ} \mathrm{C}, 15^{\circ} \mathrm{C}$, and $30^{\circ} \mathrm{C}$, respectively. While the temperature was lowered from $30^{\circ} \mathrm{C}$ to $10^{\circ} \mathrm{C}$, the removal rate of CAP decreased sharply from above $95 \%$ to below $10 \%$. Interestingly, the temperature did not significantly affect the performance of BET at $2 \%$ salinity. When the reaction temperature was varied between $30^{\circ} \mathrm{C}$ and $10^{\circ} \mathrm{C}$, the BET maintained a CAP removal efficiency of $>75 \%$. 
The effect of temperature conversion on biocathodes removal of CAP by [122, 123]. Kong et al. [122] revealed as the temperature was lowered from $25^{\circ} \mathrm{C}$ to $10^{\circ} \mathrm{C}$, the rate of CAP reduction, but at $10^{\circ} \mathrm{C}$, contrasting the abiotic cathode, it still shows a higher percentage of decline at the biocathodes. The CAP reduction reaction at current through cyclic voltammetry (CV), based on the "Geo-Chip" and "Illumina sequencing" methods using the 16S rRNA gene, Liang et al. related microorganisms and functional genes were also resolute for changes in temperature from $10^{\circ} \mathrm{C}$ to $25^{\circ} \mathrm{C}$. The major differences important genes that respond to elevated temperatures of $15^{\circ} \mathrm{C}$ include nitro-reductase and heat shock proteins, but no electron transfer genes. The excellent catalytic-stability of continuous low temperature at bio-cathodes exposed to $10^{\circ} \mathrm{C}$ was shown: (I) firstly, enrich two major taciturn adapted nitro-reductases that carry microorganisms, which were vagococcus and aeromonas; (II) maintains the relative abundance of critical electron-transferred genes [111]. Such as hydrogenated genes and cytochrome-specific genes. It was essential to evaluate the ability of large scale BESs to degrade antibiotics[2], at changing temperature. Thus, further experimental studies to understand the metabolic activity of the electrode are exposed to biofilms due to temperature and stress mechanisms [2, 10].

\section{Major Problematic Effects on the Removal of Antibiotics}

\subsection{Effects of Initial Concentration}

The effect of initial antibiotic concentrations on the efficiency of bioelectrochemical technology (BET) removal was quite complicated, as previous studies had contradictory conclusions. Some studies have publicized that the higher the concentration of antibiotics, the lower the BET removal ability [124]. Other researchers report that removal efficiency was increased with increasing antibiotic concentrations, while other studies have shown that initial antibiotic concentrations have no significant effect. It is easy to understand that the contamination load of the system increases as the initial concentration of antibiotics increases [125]. Therefore, more time is required to remove the antibiotic, and as the concentration increases, the degradation efficiency of antibiotics in the biocathodes decreases [10, 126].

\section{2. pH Optimal Range and Its Effects on Microorganisms}

The $\mathrm{pH}$ level was an important step in the anaerobic treatment process [16], and there was a need to distinguish between acidogenic and methanogenic microorganisms having an optimal $\mathrm{pH}$ [127]. If the $\mathrm{pH}$ ranged from 6.7 to 7.5 was not maintained in the anaerobic reactor, the anaerobic system may be devastated. When antibiotics are an occurrence in the anaerobic reactor, volatile fatty acids (VFA) are accumulated, and the $\mathrm{pH}$ drops. [128]. For example, it has been shown that the $\mathrm{pH}$ in the antibiotic reactor is much lower than the $\mathrm{pH}$ in the control reactor. For anaerobic digestion of swine slurry, the $\mathrm{pH}$ of chlortetracycline (CTC) containing the reactor is lower than that of the control reactor [128, 129]. Moreover, it was pointed out that the $\mathrm{pH}$ in the anaerobic reactor is sensitive to high concentrations of antibiotics [130]. As stated by Miller et al., the $\mathrm{pH}$ continues to stabilize, which lasts between 7.4 and 7.6, adding 1.0 to $5.0 \mathrm{mg} / \mathrm{L} \mathrm{SMX}$ to the reactor, then dropping the $\mathrm{pH}$ to 6.3 after $50 \mathrm{mg} / \mathrm{L}$ and added immediately to SMX in response to increased VFA [131]. It was also confirmed that the $\mathrm{pH}$ did not drop from just $(6.8-7.2)$ to 5.9 until the concentrations of TC and SMX reached $20 \mathrm{mg} / \mathrm{L}$ and $1.5 \mathrm{mg} / \mathrm{L}$, respectively [22, 132]. Therefore, the immobility of the anaerobic reactor can be influenced by the addition of high concentrations of antibiotics. However, a sharp drop in $\mathrm{pH}$ can only occur at the beginning of the anaerobic process, and the contact time between the antibiotic used and the anaerobic sludge is short and stable as the reaction proceeds [133].

\section{Microbial Communities vs. Antibiotics Degradation}

The microbial communities play an important role as a biocatalyst in the overall performance of the bioelectrochemical technology [134]. The rapid development of high quantity sequencing for the degradation of the antibiotic to explore the effective microorganisms in BET helps to understand the changes in the microbial community in response to environmental factors. Their influence on microorganisms, as well as initial antibiotic concentrations, temperature, applied potential, and salinity has been studied displayed in Table 2 . These powerful factors stand out in altering the richness and diversity of the microbial bacterial communities. The maintenance of acclimation in the Chao I, Simpson, and Shannon indices of the bacterial communities of MFCs decrease sharply, and Eubacterium spp. dominant genus in MFCs [134]. The key factors accumulate corresponding specific functional microorganisms. Biocathodes were significantly enriched based on temperature changes of $10^{\circ} \mathrm{C}$, for example, the cold-adapted ability of Aeromonas and Vagococcus gene [123]. Nevertheless, the effects of various factors vary from pharmacological and lead to significant transformations between the bacterial communities. The abundance of proteobacteria bacteria increases in biocathodes, and the potential adverse effects on the proper treatment of antibiotics CAP [124]. Whereas enriches of Firmicutes about $60.07 \%$ based on $0.8 \mathrm{~V}$ treating nitrofurazone (NFZ) group [66]. Table 2 showed the main microorganisms that can cause the degradation of antibiotics at the phylum level, three dominant organisms have its place to Proteobacteria, Bacteroidetes, and Firmicutes be present in most BET reactors. Intended for sulfamethoxazole, Thauera proficient in the degradation of aromatic hydrocarbons accompaniments in MFCs inoculating SMX acclimatised cultures [58]. The growth of the abundance of Methanobacterium, Methanosaeta, and Treponema is responsible for the degradation of exceptionally concentrated SMX-antibiotics in MFCs reported [60, 135]. CAP-electrochemically active bacterium pseudomonas occurs in all biocathodes, having the ability to decrease nitroaromatics. For antibiotics NFZ, Klebsiella bacteria play a significant role as a dominant genus about $60.57 \%$ at $0.20 \mathrm{~V}$ and $56.96 \%$ at $0.5 \mathrm{~V}$ in biocathodes, respectively [66, 136]. However, the Klebsiella spp. did not only can decrease nitro-aromatics electrochemically active similarly, but Oxytetracycline spp. was the functional 


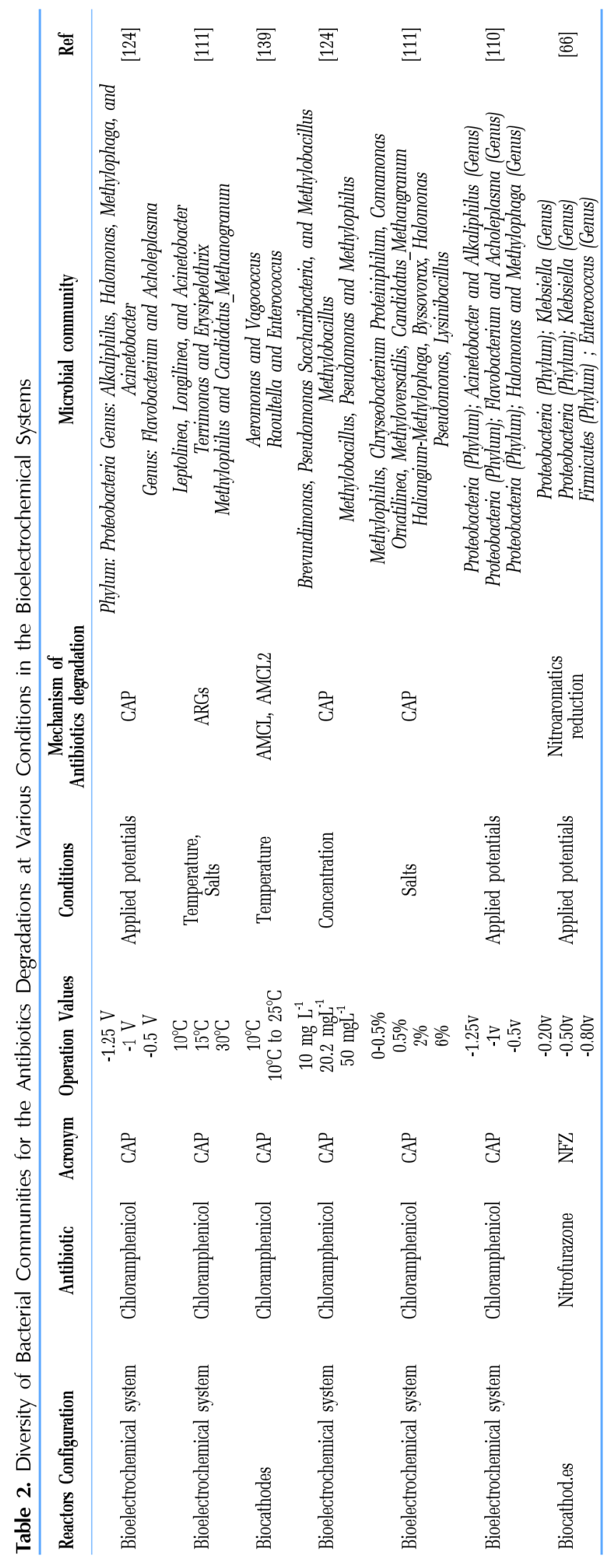

bacteria as Eubacterium spp. was fertility approximately $91.69 \pm$ $0.27 \%$ in MFCs reactor [135]. Here, some affiliates of Eubacterium spp. bacteria anaerobically change oxygen-containing heterocyclic-aromatic compounds or secrete enzymes to the catalyze-metabolic process of complex-compounds [137, 138]. For cefazolin-sodium, Acinetobacter, Stenographmonas, Geobacter, Lysinibacillus and Dysgonomonas, were detected and are liable for degradation in single-chamber MFCs through co-metabolism [65, 136]. Further considerate of efficient microbes would facilitate the rapid development of wastewater treatment containing antibiotics. Inaccessibility of virtuously functional bacteria, genome-level, metabolic modelling, and genetic engineering can provide beneficial species with superior degradation capabilities [58, $65,136]$. Immunisation of these functional species would contribute to the quick startup of biofilms and help the excellent treatment of antibiotics degradation in bioelectrochemical technology.

\section{Bacterial Diversity at the Gene Level}

Several studies have been investigated the fate of antibiotics removal from wastewater treatment plants [140], while many other studies have taken into account the environment, focusing on ARG's response to wastewater treatment $[141,142]$. However, very few studies found from the literature that has examined the occurrence and the fate of AR bacteria in WWTPs [143]. Although a considerable amount of research supported out joining the investigation of ARGs and antibiotics [144] over and above ARB and ARGs [141, 145] along the wastewater treatment process, comprehensive studies evaluating ARB, ARGs and the fate of antibiotics, in WWTPs and its final influence on getting water bodies are still lacking [146]. Each gene is amplified using a specific primer set, PCR conditions include the initial denaturation of $3 \mathrm{~min}$ at $95^{\circ} \mathrm{C}$, then 40 cycles at $95^{\circ} \mathrm{C}$, then $20 \mathrm{~s}$ at specific annealing temperature, and finally two elongation steps at $72^{\circ} \mathrm{C}$ for $40 \mathrm{~s}, 78^{\circ} \mathrm{C}$ lasts $32 \mathrm{~s}$. As well to investigate the extent of antibiotic contamination by WW, which is designed to fill prevalence and distinguish bacterial components from receiving rivers, faecal bacteria, E. coli, and the combination of nutrients that depend on nutrition and their effects of ARG, attached particles (PAB) and free Living (FLB) [9, 147]. Escherichia coli is selected as faecal to show bacteria that may be exposed to high antibiotic concentrations in the gastrointestinal tract of humans and animals, and gain resistance before being released into the sewer system and eventually reaching WWTP [146]. Therefore, high throughput quantitative PCR and functional metagenomics [148], including the abundance and diversity of ARGs, the mechanism of transmission of horizontal genes, the difference in ARGs in long-term operation [9], the expression of single and multiple antibiotics, BESs for the scientific aspects of bio-film are expected to unravel [149]. In a realistic environment, attention should be paid to the coexistence of antibiotics and other emerging substances [150], such as pharmaceuticals and personal care products (PPCPs) [151]. Hence, in addition to the feasibility of BESs joint removal of existing pollutants, the effects of substances coexisting in the electrically active biofilm antibiotic resistance genes must also be considered [151, 152]. 


\section{Knowledge Gaps and Future Perspectives}

As discussed in this review, the recent development and the performance of MFCs and MECs concerning the degradation of appropriate antibiotics were studied. In this, BES systems can remove many selected antibiotics from wastewater, which is a unique technology. However, the latest research has focused on wastewater effluents containing antibiotics and many other types of pollutants. Due to the physicochemical properties of wastewater containing antibiotics and their impact on microbial communities in anaerobic reactors, however, further investigation is needed to understand the mechanism by which BES removes and responds to other antibiotics. Most of the scientific studies on the anaerobic degradation of antibiotic conversion products and their Eco-toxicity or health risks are needed. For analysis of the effects of antibiotics on BES, microbes are required to understand their impact on various factors. However, there are several types of medicines in wastewater, and further research is needed to check the removal limits under different operating conditions. Although the significant progress in BESs antibiotic removal capacity is relatively low, given the future application of realistic pollution in the environment. In the future, it is necessary to investigate the influence of microbial communities on electron transfer and the comparison between electrodes. Moreover, it needs further study to improve the interaction between bio-electrodes and electron transfer medium by adding and removing the ability of electronic transfer medium and electrochemical active microorganism.

\section{Concluding Remarks}

This review on bioelectrochemical technologies should be developed for different environments, including the removal capacity of solid substrates containing antibiotics and the problematic effects on microbial communities. BES technology is almost still a relatively new technology in the experimental phase, but since the configuration of MFCs and MECs has so far achieved excellent performance, the removal of pollutants and the generation of electricity from the substrate. Therefore, the first and most important measure is to reduce the unnecessary use of antibiotics to address the problem at the source. Some BES systems show the possibility of complete mineralisation, including antibiotics with low energy costs. The hybrid MFC-coupled constructed wetlands and MFC-MEC systems have been proposed, and further research is needed to assess the removal performance of antibiotics.

\section{Acknowledgment}

This work was funded by the National Natural Science Foundation of China (Project No. 51578132)

\section{Authors Contributions}

M.H. (Ph.D. Student) wrote novel review articles with the help of Supervisor and group teachers. G.Z. (Ph.D.) provided suggestion and authoritative points to write a novel review. Y-Z.L. (Ph.D.) participated in drafting the article. A.H.Al-F. (Ph.D. Student) contributed substantially to the conception and design of the study. Y.L. (Ph.D. Student) revised it critically for important intellectual facts. S.H. (Ph.D. Student) drafted or provided critical revision of the article. Z.W. (Ph.D. Student) agreed to be accountable for all aspects of the work and also revised the manuscript.

\section{References}

1. Amos GC, Ploumakis S, Zhang L, et al. The widespread dissemination of integrons throughout bacterial communities in a riverine system. The ISME J. 2018;12:681-691.

2. Kummerer K. Antibiotics in the aquatic environment--a review--part II. Chemosphere 2009;75:417-434.

3. Sabri N, Schmitt H, Van der Zaan B, et al. Prevalence of antibiotics and antibiotic resistance genes in a wastewater effluent-receiving river in the Netherlands. J. Environ. Chem. Eng. 2018;18:102-245.

4. Li WC. Occurrence, sources, and fate of pharmaceuticals in aquatic environment and soil. Environ. Pollut. 2014;187:193-201.

5. Guo W, Song H, Zhou L, et al. Simultaneous removal of sulfanilamide and bioelectricity generation in two-chambered microbial fuel cells. Desalin. Water Treat. 2016;57:24982-24989.

6. Bajracharya S, Sharma M, Mohanakrishna G, et al. An overview on emerging bioelectrochemical systems (BESs): Technology for sustainable electricity, waste remediation, resource recovery, chemical production and beyond. Renew. Energ. 2016;98:153-170.

7. Berendonk TU, Manaia CM, Merlin C, et al. Tackling antibiotic resistance: the environmental framework. Nat. Rev. Microbiol. 2015;13:310-317.

8. Laxminarayan R, Duse A, Wattal C, et al. Antibiotic resistancethe need for global solutions. Lancet Infect. Dis. 2013;13:1057-1098.

9. Lorenzo P, Adriana A, Jessica S, et al. Antibiotic resistance in urban and hospital wastewaters and their impact on a receiving freshwater ecosystem. Chemosphere 2018;206:70-82.

10. Martinez JL. Environmental pollution by antibiotics and by antibiotic resistance determinants. Environ. Pollut. 2009;157: 2893-2902.

11. Waksman SA. What is an antibiotic or an antibiotic substance? Mycologia 1947;39:565-569.

12. Chang Y-T, Yang C-W, Chang Y-J, Chang T-C, Wei D-J. The treatment of PPCP-containing sewage in an anoxic/aerobic reactor coupled with a novel design of solid plain graphite-plates microbial fuel cell. J. Biomed. Biotechnol. 2014;2014:765652.

13. Avisar D, Lester Y, Mamane H. pH induced polychromatic UV treatment for the removal of a mixture of SMX, OTC and CIP from water. J. Hazard. Mater. 2010;175:1068-1074.

14. Brown KD, Kulis J, Thomson B, et al. Occurrence of antibiotics in hospital, residential, and dairy effluent, municipal wastewater, and the Rio Grande in New Mexico. Sci. Total Environ. 2006;366:772-783.

15. Zhou H, Smith DW. Advanced technologies in water and wastewater treatment. J. Environ. Eng. Sci. 2002;1:247-264.

16. Andreozzi R, Caprio V, Insola A, Marotta R. Advanced oxidation 
processes (AOP) for water purification and recovery. Catal. Today 1999;53:51-59.

17. Cheng D, Ngo H, Guo W, et al. Problematic effects of antibiotics on anaerobic treatment processes in swine wastewater. Bioresour. Technol. 2018;263:642-653

18. Londoño YA, Peñuela GA. Biological removal of different concentrations of ibuprofen and methylparaben in a sequencing batch reactor (SBR). Water Air Soil Pollut. 2015;226:393.

19. Tom Frieden. Antibiotic resistance threats in the United States, 2013. Centers for Disease Control and Prevent; 2013.

20. Kronenberg M, Trably E, Bernet N, et al. Biodegradation of polycyclic aromatic hydrocarbons: using microbial bioelectrochemical systems to overcome an impasse. Environ. Pollut. 2017;231:509-523.

21. Hasany M, Mardanpour MM, Yaghmaei S. Biocatalysts in microbial electrolysis cells: A review. Int. J. Hydrog. Energ. 2016;41:1477-1493.

22. Feng L, Casas ME, Ottosen LDM, et al. Removal of antibiotics during the anaerobic digestion of pig manure. Sci. Total Environ. 2017;603:219-225.

23. Harnisch F, Gimkiewicz C, Bogunovic B, et al. On the removal of sulfonamides using microbial bioelectrochemical systems. Electrochem. Commun. 2013;26:77-80.

24. Zhang S, Song H-L, Yang X-L, et al. Effect of electrical stimulation on the fate of sulfamethoxazole and tetracycline with their corresponding resistance genes in three-dimensional biofilm-electrode reactors. Chemosphere 2016;164:113-119.

25. Song H-L, Zhang S, Yang X-L, et al. Coupled effects of electrical stimulation and antibiotics on microbial community in three-dimensional biofilm-electrode reactors. Water Air Soil Pollut. 2017;228:83.

26. Cicek N. A review of membrane bioreactors and their potential application in the treatment of agricultural wastewater. Can. Biosyst. Eng. 2003;45:6.37-6.49

27. Petrović M, Gonzalez S, Barceló D. Analysis and removal of emerging contaminants in wastewater and drinking water. Trac-Trend Anal. Chem. 2003;22:685-696.

28. Sharma M, Bajracharya S, Gildemyn S, et al. A critical revisit of the key parameters used to describe microbial electrochemical systems. Electrochimica. Acta. 2014;140:191-208.

29. Cecconet D, Molognoni D, Callegari A, et al. Biological combination processes for efficient removal of pharmaceutically active compounds from wastewater: a review and future perspectives. J. Environ. Chem. Eng. 2017;5:3590-3603.

30. Wu D, Sun F, Zhou Y. Degradation of Chloramphenicol with Novel Metal Foam Electrodes in Bioelectrochemical Systems. Electrochimica. Acta. 2017;240:136-145.

31. Zhang S, Song H-L, Yang X-L, et al. Dynamics of antibiotic resistance genes in microbial fuel cell-coupled constructed wetlands treating antibiotic-polluted water. Chemosphere 2017;178:548-555.

32. Jiang C, Liu L, Crittenden JC. An electrochemical process that uses an $\mathrm{Fe} 0 / \mathrm{TiO} 2$ cathode to degrade typical dyes and antibiotics and a bio-anode that produces electricity. Front. Environ. Sci. Eng. 2016;10:1-10.

33. Zhang S, Song H-L, Yang X-L, Li H, Wang YW. A system composed of a biofilm electrode reactor and a microbial fuel cell-con- structed wetland exhibited efficient sulfamethoxazole removal but induced sul genes. Bioresour. Technol. 2018;256:224-231.

34. Yang W, Han H, Zhou M, Yang J. Simultaneous electricity generation and tetracycline removal in continuous flow electrosorption driven by microbial fuel cells. RSC $A d v$. 2015;5: 49513-49520.

35. Obayiuwana A, Ogunjobi A, Yang $M$, Ibekwe $M$. Characterization of bacterial communities and their antibiotic resistance profiles in wastewaters obtained from pharmaceutical facilities in Lagos and Ogun States, Nigeria. Int. J. Environ. Res. Public health. 2018;15:1365.

36. Mutiyar PK, Mittal AK. Risk assessment of antibiotic residues in different water matrices in India: key issues and challenges. Environ. Sci. Pollut. Res. 2014;21:7723-7736.

37. Piña B, Bayona JM, Christou A, et al. On the contribution of reclaimed wastewater irrigation to the potential exposure of humans to antibiotics, antibiotic resistant bacteria and antibiotic resistance genes-NEREUS COST Action ES1403 position paper. J. Environ. Chem. Eng. 2020;8:102-131.

38. Krzeminski P, Tomei MC, Karaolia P, et al. Performance of secondary wastewater treatment methods for the removal of contaminants of emerging concern implicated in crop uptake and antibiotic resistance spread: A review. Sci. Total Environ. 2019;648:1052-1081.

39. Robinson TP, Bu D, Carrique-Mas J, et al. Antibiotic resistance is the quintessential One Health issue. Transact Royal Soci Trop Med Hyg. 2016;110:377-380.

40. Pant D, Singh A, Van Bogaert G, et al. Bioelectrochemical systems (BES) for sustainable energy production and product recovery from organic wastes and industrial wastewaters. Rsc Adv. 2012;2:1248-1263.

41. Pant D, Van Bogaert G, Diels L, Vanbroekhoven K. A review of the substrates used in microbial fuel cells (MFCs) for sustainable energy production. Bioresour. Technol. 2010;101:1533-1543.

42. Shi L, Wang W, Yuan S-J, Hu Z-H. Electrochemical stimulation of microbial roxarsone degradation under anaerobic conditions. Environ. Sci. Technol. 2014;48:7951-7958.

43. Tenover FC. Mechanisms of antimicrobial resistance in bacteria. Am J infect control. 2006;34:S3-S10.

44. Busalmen JP, de Sánchez SR Electrochemical polarization-induced changes in the growth of individual cells and biofilms of Pseudomonas fluorescens (ATCC 17552). Appl. Environ. Microbiol. 2005;71:6235-6240.

45. Hibino M, Shigemori M, Itoh $\mathrm{H}$, et al. Membrane conductance of an electroporated cell analyzed by submicrosecond imaging of transmembrane potential. Biophys. J. 1991;59:209-220.

46. Cheng Z, Hu X, Sun Z Microbial community distribution and dominant bacterial species analysis in the bio-electrochemical system treating low concentration cefuroxime. Chem. Eng. J. 2016;303:137-144.

47. Logan BE. Microbial fuel cells: John Wiley \& Sons; 2008.

48. Rozendal RA, Hamelers HV, Rabaey K, et al. Towards practical implementation of bioelectrochemical wastewater treatment. Trends Biotechnol. 2008;26:450-459.

49. Yan W, Xiao Y, Yan W, et al. The effect of bioelectrochemical systems on antibiotics removal and antibiotic resistance genes: A review. Chem. Eng. J. 2019;358:1421-1437. 
50. Zhou M, Chi M, Luo J, He H, Jin T. An overview of electrode materials in microbial fuel cells. J. Power Sour. 2011;196:4427-4435.

51. Wei J, Liang P, Huang X Recent progress in electrodes for microbial fuel cells. Bioresour. Technol. 2011;102:9335-9344.

52. Zhang S, Song H-L, Yang X-L, et al. Fate of tetracycline and sulfamethoxazole and their corresponding resistance genes in microbial fuel cell coupled constructed wetlands. RSC Adv. 2016;6:95999-96005.

53. Zhang L, Yin X, Li SFY. Bio-electrochemical degradation of paracetamol in a microbial fuel cell-Fenton system. Chem. Eng. J. 2015;276:185-192.

54. Werner CM, Hoppe-J C, Saikaly PE, et al. Attenuation of trace organic compounds (TOrCs) in bioelectrochemical systems. Water Res. 2015;73:56-67.

55. Wang L, Liu Y, Ma J, Zhao F. Rapid degradation of sulphamethoxazole and the further transformation of 3-amino-5-methylisoxazole in a microbial fuel cell. Water Res. 2016;88:322-328.

56. Gusseme BD, Soetaert M, Hennebel T, et al. Catalytic dechlorination of diclofenac by biogenic palladium in a microbial electrolysis cell. Microb. Biotechnol. 2012;5:396-402.

57. Wen Q, Kong F, Zheng H, et al. Electricity generation from synthetic penicillin wastewater in an air-cathode single chamber microbial fuel cell. Chem. Eng. J. 2011;168:572-576.

58. Miran W, Jang J, Nawaz M, et al. Biodegradation of the sulfonamide antibiotic sulfamethoxazole by sulfamethoxazole acclimatized cultures in microbial fuel cells. Sci. Total Environ. 2018;627:1058-1065.

59. Wang J, He M-F, Zhang D, et al. Simultaneous degradation of tetracycline by a microbial fuel cell and its toxicity evaluation by zebrafish. RSC Adv. 2017;7:44226-44233.

60. Wang L, Wu Y, Zheng Y, et al. Efficient degradation of sulfamethoxazole and the response of microbial communities in microbial fuel cells. RSC Adv. 2015;5:56430-56437.

61. Yan W, Guo Y, Xiao Y, et al. The changes of bacterial communities and antibiotic resistance genes in microbial fuel cells during long-term oxytetracycline processing. Water Res. 2018;142:105-114

62. Li Y, Liu L, Yang F Destruction of tetracycline hydrochloride antibiotics by $\mathrm{FeOOH} / \mathrm{TiO}_{2}$ granular activated carbon as expanded cathode in low-cost MBR/MFC coupled system. $J$. Membr. Sci. 2017;525:202-209.

63. Zhang Q, Zhang Y, Li D Cometabolic degradation of chloramphenicol via a meta-cleavage pathway in a microbial fuel cell and its microbial community. Bioresour. Technol. 2017;229:104-110.

64. Guo W, Geng M, Song H, et al. Removal of chloramphenicol and simultaneous electricity generation by using microbial fuel cell technology. Int. J. Electrochem. Sci. 2016;11:5128-139.

65. Zhang E, Yu Q, Zhai W, et al. High tolerance of and removal of cefazolin sodium in single-chamber microbial fuel cells operation. Bioresour. Technol. 2018;249:76-81.

66. Kong D, Yun H, Cui D, et al. Response of antimicrobial nitrofurazone-degrading biocathode communities to different cathode potentials. Bioresour. Technol. 2017;241:951-958.

67. Song H, Guo W, Liu M, et al. Performance of microbial fuel cells on removal of metronidazole. Water Sci. Technol. 2013;68:2599-2604

68. Huang L, Cheng S, Chen G. Bioelectrochemical systems for efficient recalcitrant wastes treatment. J. Chem. Technol. Biotechnol. 2011;86:481-491.

69. Cui M-H, Cui D, Lee H-S, et al. Effect of electrode position on azo dye removal in an up-flow hybrid anaerobic digestion reactor with built-in bioelectrochemical system. Sci. Rep. 2016;6:25223.

70. Yuan H, Miller JH, Abu-Reesh IM, et al. Effects of electron acceptors on removal of antibiotic resistant Escherichia coli, resistance genes and class 1 integrons under anaerobic conditions. Sci. Total Environ. 2016;569:1587-1594.

71. Jafary T, Daud WRW, Ghasemi M, et al. Biocathode in microbial electrolysis cell; present status and future prospects. Renew Sust. Energ. Rev. 2015;47:23-33.

72. Kim BH, Lim SS, Daud WRW, et al. The biocathode of microbial electrochemical systems and microbially-influenced corrosion. Bioresour. Technol. 2015;190:395-401.

73. Rosenbaum MA, Franks AE. Microbial catalysis in bioelectrochemical technologies: status quo, challenges and perspectives. Appl. Microb. Biotechnol. 2014;98:509-518.

74. Yuan H, Hou Y, Abu-Reesh IM, et al. Oxygen reduction reaction catalysts used in microbial fuel cells for energy-efficient wastewater treatment: a review. Mater. Horiz. 2016;3:382-401.

75. Dominguez-Benetton X, Varia JC, Pozo G, et al. Metal recovery by microbial electro-metallurgy. Prog. Mater. Sci. 2018;94: 435-461

76. Xia X, Li M, Liu T, et al. Facile synthesis of cobalt oxide as electrocatalyst for the oxygen reduction reaction in microbial fuel cells. Chem. Eng. J. 2018;342:395-400.

77. Sun F, Liu H, Liang B, et al. Reductive degradation of chloramphenicol using bioelectrochemical system (BES): A comparative study of abiotic cathode and biocathode. Bioresour. Technol. 2013;143:699-702.

78. Wang H, Heil D, Ren ZJ, Xu P. Removal and fate of trace organic compounds in microbial fuel cells. Chemosphere 2015;125: 94-101.

79. Pérez S, Eichhorn P, Aga DS. Evaluating the biodegradability of sulfamethazine, sulfamethoxazole, sulfathiazole, and trimethoprim at different stages of sewage treatment. Environ. Toxicol. Chem: An. Int. J. 2005;24:1361-1367.

80. Zhu Y-G, Zhao Y, Li B, et al. Continental-scale pollution of estuaries with antibiotic resistance genes. Nat. Microbiol. 2017;2:16270

81. Wen Q, Kong F, Zheng H, et al. Simultaneous processes of electricity generation and ceftriaxone sodium degradation in an air-cathode single chamber microbial fuel cell. J. Power Source. 2011;196:2567-2572.

82. Wang J, Wang S. Microbial degradation of sulfamethoxazole in the environment. Appl. Microbiol. Biot. 2018;102:3573-3582.

83. Dantas RF, Contreras S, Sans C, Esplugas S. Sulfamethoxazole abatement by means of ozonation. J. hazard. Mater. 2008;150: 790-794.

84. González O, Sans C, Esplugas S. Sulfamethoxazole abatement by photo-Fenton: toxicity, inhibition and biodegradability assessment of intermediates. J. Hazard. Mater. 2007;146:459-464.

85. Chu X, Shan G, Chang C, et al. Effective degradation of tetracycline by mesoporous $\mathrm{Bi}_{2} \mathrm{WO}_{6}$ under visible light irradiation. Fron. Env. Sci. Eng. 2016;10:211-218. 
86. Feng L, van Hullebusch ED, Rodrigo MA, et al. Removal of residual anti-inflammatory and analgesic pharmaceuticals from aqueous systems by electrochemical advanced oxidation processes. A review. Chem. Eng. J. 2013;228:944-964.

87. Wright GD. Bacterial resistance to antibiotics: enzymatic degradation and modification. Adv. Drug Deliv. Rev. 2005;57:1451-1470.

88. De Gusseme B, Hennebel T, Vanhaecke L, et al. Biogenic palladium enhances diatrizoate removal from hospital wastewater in a microbial electrolysis cell. Environ. Sci. Technol. 2011;45:5737-5745.

89. Flores H G, Feria Solorza O,Varaldo Poggi HM. Bioelecrtricity generation from wastewater and actual landfill leachates: A multivariate analysis using principal component analysis. Int. J. Hydrog. Energ. 2017;42:20777-20782.

90. Zhang G, Feng S, Jiao Y, et al. Cathodic reducing bacteria of dual-chambered microbial fuel cell. Int. J. Hydrog. Energ. 2017;42:27607-27617.

91. Wang X-c, Shen J-m, Chen Z-l, et al. Removal of pharmaceuticals from synthetic wastewater in an aerobic granular sludge membrane bioreactor and determination of the bioreactor microbial diversity. Appl. Microbiol. Biot. 2016;100:8213-8223.

92. Sadabad Rasouli H, Gholikandi BG. Simultaneous effective sludge stabilization and direct electricity generation by merging microbial fuel cell (MFC) and Fered-Fenton reactor:An experimental study. Biomass. Bioenerg.2018;119:75-89

93. Birjandi N, Younesi H, Ghoreyshi AA, Rahimnejad M. Electricity generation through degradation of organic matters in medicinal herbs wastewater using bio-electro-Fenton system. J. Environ. Manage. 2016;180:390-400.

94. Ghernaout D, Elboughdiri N, Ghareba S. Fenton Technology for Wastewater Treatment: Dares and Trends. OALib. J. 2020;7:1-26.

95. Ghernaout D, Elboughdiri N. Water Disinfection: Ferrate (VI) as the Greenest Chemical—A Review. Appl. Eng. 2019;3:171-180.

96. Recio-Garrido D, Perrier M, Tartakovsky B. Modeling, optimization and control of bioelectrochemical systems. Chem. Eng. J. 2016;289:180-190.

97. Kadier A, Kalil MS, Abdeshahian P, et al. Recent advances and emerging challenges in microbial electrolysis cells (MECs) for microbial production of hydrogen and value-added chemicals. Renew. Sust. Energ. Rev. 2016;61:501-525.

98. Mohan SV, Velvizhi G, Modestra JA, Srikanth S. Microbial fuel cell: critical factors regulating bio-catalyzed electrochemical process and recent advancements. Renew. Sust. Energ. Rev. 2014;40:779-797.

99. Saratale RG, Saratale GD, Pugazhendhi A, et al. Microbiome involved in microbial electrochemical systems (MESs): A review. Chemosphere 2017;177:176-188.

100. Champigneux P, Delia M-L, Bergel. A Impact of electrode micro-and nano-scale topography on the formation and performance of microbial electrodes. Biosens. Bioelectron. 2018;118:231-246.

101. Yu L, Ruan S, Xu X, et al. One-dimensional nanomaterial-assembled macroscopic membranes for water treatment. Nano Today. 2017;17:79-95.

102. Jiang Z, Zhang D, Zhou L, et al. Enhanced catalytic capability of electroactive biofilm modified with different kinds of carbon nanotubes. Anal. Chim. Acta. 2018;1035:51-59.

103. You P, Kamarudin S. Recent progress of carbonaceous materials in fuel cell applications: An overview. Chem. Eng. J. 2017;309:489-502.

104. Mateo S, Cañizares P, Rodrigo MA, et al. Driving force behind electrochemical performance of microbial fuel cells fed with different substrates. Chemosphere 2018;207:313-319.

105. Chen F, Li Z-L, Yang J-q, et al. Effects of different carbon substrates on performance, microbiome community structure and function for bioelectrochemical-stimulated dechlorination of tetrachloroethylene. Chem. Eng. J. 2018;352:730-736.

106. Kumar RR, Lee JT, Cho JY. Fate, occurrence, and toxicity of veterinary antibiotics in environment. J. Korean Soc. Appl. Biol. Chem. 2012;55:701-709.

107. Commault AS, Lear G, Packer MA, Weld RJ. Influence of anode potentials on selection of Geobacter strains in microbial electrolysis cells. Bioresour. Technol. 2013;139:226-234.

108. Moscoviz R, Toledoalarcon J, Trably E, Bernet N. ElectroFermentation: How To Drive Fermentation Using Electrochemical Systems. Trends Biotechnol. 2016;34:856-865.

109. Mcmanus MC. Mechanisms of bacterial resistance to antimicrobial agents. Am. J. Health-Syst. Pharm. 1997;54:1420-1433.

110. Guo N, Wang Y, Yan L, et al. Effect of bio-electrochemical system on the fate and proliferation of chloramphenicol resistance genes during the treatment of chloramphenicol wastewater. Water Res. 2017;117:95-101.

111. Guo N, Wang Y, Tong T, Wang S. The fate of antibiotic resistance genes and their potential hosts during bio-electrochemical treatment of high-salinity pharmaceutical wastewater. Water Res. 2018;133:79-86.

112. Angelidaki I, Ellegaard L, Ahring BK. Applications of the anaerobic digestion process. Biomethanation II: Springer; 2003. p. 1-33.

113. Samaraweera DN, Liu X, Zhong G, et al. Antibiotics in two municipal sewage treatment plants in Sri Lanka: Occurrence, consumption and removal efficiency. Emerg. Contam. 2019;5:272-278.

114. Chen J, Yang Y, Liu Y, et al. Bacterial community shift and antibiotics resistant genes analysis in response to biodegradation of oxytetracycline in dual graphene modified bioelectrode microbial fuel cell. Bioresour. Technol. 2019;276: 236-243.

115. Reis AC, Kolvenbach BA, Nunes OC, et al. Biodegradation of antibiotics: The new resistance determinants-part I. New Biotechnol. 2019;54:34-51.

116. Singh HM, Pathak AK, Chopra K, et al. Microbial fuel cells: A sustainable solution for bioelectricity generation and wastewater treatment. Biofuels 2019;10:11-31.

117. Li H, Song H-L, Yang X-L, et al. A continuous flow MFC-CW coupled with a biofilm electrode reactor to simultaneously attenuate sulfamethoxazole and its corresponding resistance genes. Sci. Total Environ. 2018;637:295-305.

118. Wu W, Lesnik KL, Xu S, Wang L, Liu H. Impact of tobramycin on the performance of microbial fuel cell. Microb. Cell Fact. 2014;13:91

119. More AG, Gupta SK. Evaluation of chromium removal efficiency at varying operating conditions of a novel bio- 
electrochemical system. Bioproc. Biosyst. Eng. 2018;41:1547-1554.

120. Mulla SI, Wang H, Sun Q, Hu A, Yu C-p. Characterization of triclosan metabolism in Sphingomonas sp. strain YL-JM2C. Sci. Rep. 2016;6:21965.

121. Pan L, Li J, Li C, Tang XD, Yu GW, Wang Y. Study of ciprofloxacin biodegradation by a Thermus sp. isolated from pharmaceutical sludge. J. Hazard. Mater. 2018;343:59-67.

122. Kong D, Liang B, Lee D-J, Wang A, Ren N-Q. Effect of temperature switchover on the degradation of antibiotic chloramphenicol by biocathode bioelectrochemical system. J. Environ. Sci. 2014;26:1689-1697.

123. Liang B, Kong D, Ma J, et al. Low temperature acclimation with electrical stimulation enhance the biocathode functioning stability for antibiotics detoxification. Water Res. 2016;100:157-168.

124. Guo N, Wang Y, Yan L, et al. Effect of bio-electrochemical system on the fate and proliferation of chloramphenicol resistance genes during the treatment of chloramphenicol wastewater. Water Res. 2017;117:95-101.

125. Rahimnejad M, Adhami A, Darvari S, Zirepour A, Oh S-E. Microbial fuel cell as new technology for bioelectricity generation: A review. Alex. Eng. J. 2015;54:745-756.

126. Blaser MJ. Antibiotic use and its consequences for the normal microbiome. Science 2016;352:544-545.

127. Batstone DJ, Keller J, Blackall L. The influence of substrate kinetics on the microbial community structure in granular anaerobic biomass. Water Res. 2004;38:1390-1404.

128. Masse DI, Lu D, Masse L, Droste R. Effect of antibiotics on psychrophilic anaerobic digestion of swine manure slurry in sequencing batch reactors. Bioresour. Technol. 2000;75: 205-211.

129. Aydin S, Ince B, Ince O. Application of real-time PCR to determination of combined effect of antibiotics on Bacteria, Methanogenic Archaea, Archaea in anaerobic sequencing batch reactors. Water Res. 2015;76:88-98.

130. Chen Y, Cheng JJ, Creamer KS. Inhibition of anaerobic digestion process: A review. Bioresour. Technol. 2008;99:4044-4064.

131. Miller JH, Novak JT, Knocke WR, et al. Effect of silver nanoparticles and antibiotics on antibiotic resistance genes in anaerobic digestion. Water Environ. Res. 2013;85:411-421.

132. Aydin S, Ince B, Cetecioglu Z, et al. Combined effect of erythromycin, tetracycline and sulfamethoxazole on performance of anaerobic sequencing batch reactors. Bioresour. Technol. 2015;186:207-214.

133. Beneragama N, Lateef SA, Iwasaki M, Yamashiro T, Umetsu $\mathrm{K}$. The combined effect of cefazolin and oxytertracycline on biogas production from thermophilic anaerobic digestion of dairy manure. Bioresour. Technol. 2013;133:23-30.

134. Yan W, Guo Y, Xiao Y, et al. The changes of bacterial communities and antibiotic resistance genes in microbial fuel cells during long-term oxytetracycline processing. Water Res. 2018;142:105-114.

135. Wang L, You L, Zhang J, et al. Biodegradation of sulfadiazine in microbial fuel cells: Reaction mechanism, biotoxicity removal and the correlation with reactor microbes. J. Hazard. Mater. 2018;360:402-411.

136. Mohan SV, Velvizhi G, Modestra JA, Srikanth S. Microbial fuel cell: Critical factors regulating bio-catalyzed electrochemical process and recent advancements. Renew. Sust. Energ. Rev. 2014;40:779-797.

137. Wang L, Meselhy MR, Yan LI, et al. The Heterocyclic Ring Fission and Dehydroxylation of Catechins and Related Compounds by Eubacterium sp. Strain SDG-2, a Human Intestinal Bacterium. Chem. Pharm. Bull. 2001;49:1640-1643.

138. Schneider H, Blaut M. Anaerobic degradation of flavonoids by Eubacterium ramulus. Arch. Microbiol. 2000;173:71-75.

139. Kong D, Liang B, Yuan $\mathrm{H}$, et al. Cathodic degradation of antibiotics: Characterization and pathways analysis. Water Res. 2015;72:281-292.

140. Laht M, Karkman A, Voolaid V, et al. Abundances of tetracycline, sulphonamide and beta-lactam antibiotic resistance genes in conventional wastewater treatment plants (WWTPs) with different waste load. PloS One. 2014;9:e103705.

141. Gao P, Munir M, Xagoraraki I. Correlation of tetracycline and sulfonamide antibiotics with corresponding resistance genes and resistant bacteria in a conventional municipal wastewater treatment plant. Sci. Total Environ. 2012;421:173-183.

142. Du J, Geng J, Ren H, et al. Variation of antibiotic resistance genes in municipal wastewater treatment plant with A 2 O-MBR system. Environ. Sci. Pollut. Res. 2015;22:3715-3726.

143. Conte D, Palmeiro JK, da Silva Nogueira K, et al. Characterization of CTX-M enzymes, quinolone resistance determinants, and antimicrobial residues from hospital sewage, wastewater treatment plant, and river water. Ecotox. Environ. Safe. 2017;136:62-69.

144. Munir M, Wong K, Xagoraraki I. Release of antibiotic resistant bacteria and genes in the effluent and biosolids of five wastewater utilities in Michigan. Water Res. 2011;45:681-693.

145. Rodriguez-Mozaz S, Chamorro S, Marti E, et al. Occurrence of antibiotics and antibiotic resistance genes in hospital and urban wastewaters and their impact on the receiving river. Water Res. 2015;69:234-242.

146. Pruden A, Arabi M, Storteboom HN. Correlation between upstream human activities and riverine antibiotic resistance genes. Environ. Sci. Technol. 2012;46:11541-11549.

147. McKinney CW, Loftin KA, Meyer MT, et al. Tet and sul antibiotic resistance genes in livestock lagoons of various operation type, configuration, and antibiotic occurrence. Environ. Sci. Technol. 2010;44:6102-6109.

148. Christgen B, Yang Y, Ahammad S, et al. Metagenomics shows that low-energy anaerobic- aerobic treatment reactors reduce antibiotic resistance gene levels from domestic wastewater. Environ. Sci. Technol. 2015;49:2577-2584.

149. Meyer E, Gastmeier P, Deja M, Schwab F. Antibiotic consumption and resistance: Data from Europe and Germany. Int. J. Med. Microbiol. 2013;303:388-395.

150. Levy SB, Marshall B. Antibacterial resistance worldwide: causes, challenges and responses. Nat. Med. 2004;10:S122-S129.

151. Megraud F, Coenen S, Versporten A, et al. Helicobacter pylori resistance to antibiotics in Europe and its relationship to antibiotic consumption. Gut 2013;62:34-42.

152. Kunin CM, Lipton HL, Tupasi T, et al. Social, behavioral, and practical factors affecting antibiotic use worldwide: report of Task Force 4. Rev. Infect. Dis. 1987;9:S270-S85. 